\title{
Celebrating 50 years of problem-based learning: progress, pitfalls and possibilities
}

\author{
Virginie F. C. Servant-Miklos ${ }^{1} \cdot$ Nicole N. Woods $^{2} \cdot$ Diana H. J. M. Dolmans ${ }^{3}$
}

(c) Springer Nature B.V. 2019

Fifty years ago, McMaster University's Faculty of Medicine (as it was known at the time) embarked willy-nilly on a pedagogical experiment that, unbeknownst to its conceivers, would reverberate through higher education across the globe in the ensuing decades. The characteristics of that experiment have been described at length elsewhere (Servant-Miklos 2019a; Spaulding 1991), but what is most remarkable about it is the extent to which it shaped medical education research, and then spilled into all areas of higher education, from engineering to liberal arts, and from Brazil to China. Commemorating the $50^{\text {th }}$ anniversary of problem-based learning goes beyond just acknowledging the contribution of the pioneers of PBL to medical education (though this definitely can and has been done). It really plugs us into key current debates about pedagogy and education research in and beyond the health sciences education sphere.

Let's start with the recognition that PBL did indeed radically transform medical education over the past 50 years. Of course, not every medical school in the world uses PBL today, and even among those that do, the quality and quantity of implementation varies greatly. But the diffusion of PBL in medical schools around the world changed the discourse around medical education, challenging old notions of the division between basic sciences and clinical skills, and questioning traditional, top-down forms of contents delivery. This is especially true in schools located near deprived communities in the Global South where PBL was interpreted as an opportunity for engaging students in community outreach from the earliest years of their medical education. Outside of medical education, the spread and implementation of PBL has been haphazard, but nonetheless enthusiastic. All manner of creative interpretations have emerged, quite often in a grassroots manner, at the behest of inspired teachers looking to do things differently, in some cases with greater success than others. What this has created is a vibrant community of educators and scholars around

Virginie F. C. Servant-Miklos

servant@euc.eur.nl

Nicole N. Woods

Nikki.Woods@utoronto.ca

Diana H. J. M. Dolmans

d.dolmans@maastrichtuniversity.nl

1 Erasmus University College, Rotterdam, The Netherlands

2 Department of Family and Community Medicine, University of Toronto, Toronto, ON, Canada

3 School of Health Professions Education (SHE), Maastricht University, Maastricht, The Netherlands 
the world, engaging in discussion and debates about problem-based education. We hope that this special issue of Advances in Health Sciences Education will provide a fruitful contribution to that conversation as we commemorate the $50^{\text {th }}$ anniversary of PBL with a series of papers discussing the historical origins of PBL, the spread of the approach across the globe and some key considerations for its use in the future.

While we celebrate the successes of PBL, it is important to recognise that the diffusion of PBL certainly hasn't come challenge-free. As Neville et al. (2019) point out in their opening salvo, the initial promise that PBL could be "everything to everyone" soon hit against the hard reality of implementation, and the realisation that the developing science of cognitive psychology could actually come in support of some PBL practices and invalidate others. This was a bitter pill to swallow for some PBL enthusiasts whose vision for the method did not necessarily line up with the evidence emerging from the cognitive research, and led to intellectual disputes over the nature and purpose of PBL, particularly over the question of problem-solving skills, that remain unresolved in practice to this day (ServantMiklos 2019b). As Wyer (2019) points out, these debates had consequences outside of the medical classroom. He argues that Evidence Based Medicine, the historical twin of PBL brewed from the same cauldron at McMaster, suffered from similar mistaken assumptions about the cognitive mechanisms at play in the process of learning.

Dolmans (2019) demonstrates the consequences of such theoretical misunderstandings on practice and makes a convincing case for investing in educational research into the theoretical underpinnings of PBL to support practice. The consequences of not doing so are quite plain to see in Kwan's (2019) vivid description of the meanderings of PBL in Asia, where cultural factors cumulate with misunderstandings about core concepts underlying the pedagogy, leaving PBL literally lost in translation at times.

The agenda for ironing out the confusions about PBL in theory and practice is laid out by van der Vleuten and Schuwirth (2019), Wijnia and Servant-Miklos (2019), Frambach et al. (2019), and Hung et al. (2019). The first two papers call for specific alignment between theory and practice in the domains of assessment and motivation. The last two articles call for a more sweeping implementation of PBL research in domains across the board, particularly taking into account the different characteristics of PBL in the different contexts in which it is implemented. This is an important point for the current and future practice of PBL: as Frambach et al. (2019) and Hung et al. (2019) point out, there are manifold manifestations of PBL in practice. This might displease purists who cling to "the original" PBL model with quasi-religious fervour (though in practice, that original model hardly existed at all), but given the reality of the diverse manner in which PBL has been implemented inside and outside of medical education, it certainly is worth asking: "why does PBL with particular implementation characteristics for specific outcomes work or not work in the condition where it is implemented?", as Hung et al. (2019) suggest.

The great diversity of practices associated with the term "PBL" is illustrated by Stentoft (2019) who describes the case of Aalborg University, where PBL has been interpreted as a form of project-based learning, and within the medical faculty whipped up into a hybrid model that uses both the traditional paper patient cases pioneered at McMaster in the 70s, and student-directed, problem-oriented projects in a complementary manner. Although we should definitely caution against calling everything and anything "problem-based learning", and heed the calls made in this special issue about the importance of theoretical support of any educational intervention, there is clearly a craving for innovation within the PBL community. In their closing paper, Noordegraaf-Eelens et al. (2019) perhaps best illustrate the potential for reinventing PBL in the light of the massive societal and environmental challenges facing higher education today. We can only agree with them that one consequence of the strong emphasis on individual cognition and metrics, while beneficial to the systematisation and effectiveness of 
PBL, is the strict focus on student's personal learning process, at the expense of understanding the social context in which the student learns. As the social structures we have taken for granted since the end of the second world war buckle under pressure from the environmental crisis, the financial crisis, the inequality crisis, and the crisis of confidence in democracy and global citizenship, higher education, including medical education, simply cannot carry on with the illusion that its sole purpose is assisting students with knowledge acquisition. There must be a recognition that knowledge is constructed in the social world, and has real world consequences outside the walls of the university. PBL has the potential to be more than just a more interesting way of imparting content. The students are clamoring for more. It is time for our community of educators and scholars to catch up with the times and provide higher education with a theoretically sound, socially engaged, better way of learning. Fifty years on, the times have changed, and the crises seem more intractable, but this call for relevance is not all too different from the ideals espoused by PBL's founding fathers.

\section{References}

Dolmans, D. H. J. M. (2019). How theory and design-based research can mature PBL practice and research. Advances in Health Sciences Education. https://doi.org/10.1007/s10459-019-09940-2.

Frambach, J. M., Talaat, W., Wasenitz, S., \& Martimianakis, M. A. (2019). The case for plural PBL: An analysis of dominant and marginalized perspectives in the globalization of problem-based learning. Advances in Health Sciences Education. https://doi.org/10.1007/s10459-019-09930-4.

Hung, W., Dolmans, D. H. J. M., \& van Merriënboer, J. J. (2019). A review to identify key perspectives in PBL meta-analyses and reviews: Trends, gaps and future research directions. Advances in Health Sciences Education. https://doi.org/10.1007/s10459-019-09945-x.

Kwan, C. Y. (2019). A thorny path: The developmental course of problem-based learning for health sciences education in Asia. Advances in Health Sciences Education. https://doi.org/10.1007/s10459-019-09920-6.

Neville, A., Norman, G. R., \& White, R. (2019). McMaster at 50: Lessons learned from five decades of PBL. Advances in Health Sciences Education. https://doi.org/10.1007/s10459-019-09908-2.

Noordegraaf-Eelens, L., Kloeg, J., \& Noordzij, G. (2019). PBL and sustainable education: Addressing the problem of isolation. Advances in Health Sciences Education. https://doi.org/10.1007/s10459-019-09927-z.

Servant-Miklos, V. F. C. (2019a). Fifty years on: A retrospective on the world's first problem-based learning programme at McMaster University Medical School. Health Professions Education, 5(1), 3-12.

Servant-Miklos, V. F. C. (2019b). Problem solving skills versus knowledge acquisition: The historical dispute that split problem-based learning into two camps. Advances in Health Sciences Education, 24(3), $619-635$.

Spaulding, W. B. (1991). Revitalizing medical education, McMaster Medical School the early years 1965-1974. Hamilton, ON: B.C. Decker Inc.

Stentoft, D. (2019). Problem-based projects in medical education: Extending PBL practices and broadening learning perspectives. Advances in Health Sciences Education. https://doi.org/10.1007/s10459-019-09917 -1 .

Van der Vleuten, C. P., \& Schuwirth, L. W. (2019). Assessment in the context of problem-based learning. Advances in Health Sciences Education. https://doi.org/10.1007/s10459-019-09909-1.

Wijnia, L., \& Servant-Miklos, V. (2019). Behind the times: A brief history of motivation discourse in problembased learning. Advances in Health Sciences Education. https://doi.org/10.1007/s10459-019-09923-3.

Wyer, P. (2019). Evidence-based medicine and problem based learning a critical re-evaluation. Advances in Health Sciences Education. https://doi.org/10.1007/s10459-019-09921-5.

Publisher's Note Springer Nature remains neutral with regard to jurisdictional claims in published maps and institutional affiliations. 